\title{
Phosphoric acid - a potentially elusive participant in atmospheric new particle formation
}

\section{Elm, Jonas}

2017

Elm , J , Myllys , N \& Kurten , T 2017 , ' Phosphoric acid - a potentially elusive participant in atmospheric new particle formation ' , Molecular Physics , vol. 115 , no. 17-18 , pp.

2168-2179 . https://doi.org/10.1080/00268976.2016.1262558

http://hdl.handle.net/10138/271660

https://doi.org/10.1080/00268976.2016.1262558

acceptedVersion

Downloaded from Helda, University of Helsinki institutional repository.

This is an electronic reprint of the original article.

This reprint may differ from the original in pagination and typographic detail.

Please cite the original version. 


\title{
ARTICLE TEMPLATE
}

\section{Phosphoric Acid - A Potentially Elusive Participant in Atmospheric New Particle Formation}

\author{
Jonas Elm ${ }^{\mathrm{a}}$, Nanna Myllys ${ }^{\mathrm{a}}$ and Theo Kurtén ${ }^{\mathrm{b}}$ \\ a University of Helsinki, Department of Physics, Helsinki, Finland \\ b University of Helsinki, Department of Chemistry, Helsinki, Finland
}

\author{
ARTICLE HISTORY \\ Compiled September 14, 2016
}

\begin{abstract}
We investigate the molecular interactions between phosphoric acid $\left(\mathrm{H}_{3} \mathrm{PO}_{4}\right)$ and common atmospheric nucleation precursors $\left(\mathrm{H}_{2} \mathrm{O}, \mathrm{NH}_{3}\right.$ and $\left.\mathrm{H}_{2} \mathrm{SO}_{4}\right)$ using computational methods. The equilibrium geometries and vibrational frequencies are obtained using the three DFT functionals M06-2X, PW91 and $\omega$ B97X-D. The single point energy is corrected using a high level CCSD(T)-F12a/VDZ-F12 calculation. The molecular interaction between phosphoric acid and sulfuric acid is found to be strong with reaction free energy of similar magnitude as the interaction between dimethylamine and sulfuric acid. The strong hydrogen bonding of phosphoric acid to sulfuric acid, indicates that concentrations of $\mathrm{H}_{3} \mathrm{PO}_{4}$ as low as $10^{2}-10^{4}$ molecules $/ \mathrm{cm}^{3}$ will offer equivalent or higher stability as the sulfuric acid dimer for the formation of atmospheric molecular clusters. We assess and utilize the DLPNO-CCSD $(\mathrm{T})$ method for studying larger clusters involving phosphoric acid and sulfuric acid and find that having a phosphoric acid molecule present in the cluster enhances the further addition of sulfuric acid molecules.
\end{abstract}

\section{KEYWORDS}

Cluster Formation, Thermochemistry, Density Functional Theory, Atmospheric Chemistry.

\section{Introduction}

Hydrogen-bonded molecular clusters are important for the formation of aerosols in the atmosphere. Aerosols interact with solar radiation by scattering the incoming light, and thereby cool the global climate [1]. The underlying mechanism for atmospheric new particle formation still largely remain a mystery. It is certain that sulfuric acid is a key component [2], but another stabilizing compound is required to explain observed new particle formation rates $[3,4]$. The predominantly investigated stabilizers are bases such as ammonia [5-12] and monoamines [13-23]. Amines have been shown to have an especially strong interaction with sulfuric acid, with a few ppt of dimethylamine yielding new particle formation rates of up to three orders of magnitude higher than ammonia [24]. Recent studies has shown that diamines clustering with sulfuric acid is an even more potent source of new particles than monoamines [25, 26]. Highly oxidized organic molecules such as carboxylic acids [27-42] and products formed via autoxidation [43-49] has also been suggested to form clusters directly with sulfuric 
acid [50-52]. However, the volatility of autoxidation products might not be as low as initially assumed and there is still no conclusive evidence of their involvement in new particle formation $[53,54]$.

Sulfuric acid is created in the atmosphere by oxidation of reduced sulfur compounds, with the final step being the hydrolysis of sulfur trioxide:

$$
\mathrm{SO}_{3}+\mathrm{H}_{2} \mathrm{O} \rightarrow \mathrm{H}_{2} \mathrm{SO}_{4}
$$

The detection of phosphine $\left(\mathrm{PH}_{3}\right)$ gas in the upper troposphere indicates that reduced phosphorus species undergo atmospheric transport [55]. Measured concentrations of $\mathrm{PH}_{3}$ is found to accumulate in the atmosphere at night time and decrease until noon of the following day. This indicates that oxidation reactions with $\mathrm{OH}$ radicals are a significant sink for $\mathrm{PH}_{3}$ [56]. Similarly to the oxidation cycle which leads to sulfuric acid, the oxidation of $\mathrm{PH}_{3}$ by $\mathrm{OH}$ radicals will eventually lead to phosphoric acid $\left(\mathrm{H}_{3} \mathrm{PO}_{4}\right)$. This could explain the finding of soluble phosphate in rain water [57]. Morton and Edwards indicated that up to $10 \%$ of the global atmospheric phosphorus flux is linked to phosphine gas [58]. However, studies on the ability of phosphorus compounds to form clusters in the atmosphere are sparse. Using a combination of matrix isolation Fourier transform infrared spectroscopy experiments and quantum chemical calculations, the ability of phosphorus to act as a hydrogen bond acceptor has recently been elucidated. Studying three trimethylphosphine - alcohol complexes, Hansen et al. showed that phosphorus can participate in the formation of $\mathrm{O}-\mathrm{H} \cdots \mathrm{P}$ hydrogen bonds in the gas phase [59]. Using similar methods Møller et al. have observed the N-H $\cdots \mathrm{P}$ hydrogen bond in the dimethylamine - trimethylphosphine complex in the gas phase [60].

No studies have addressed the potential of phosphorus compounds to participate in cluster formation relevant to atmospheric new particle formation. Being a highly hygroscopic acid, phosphoric acid could analogous to sulfuric acid participate in new particle formation. To our knowledge there is currently no measurements on the atmospheric concentration of phosphoric acid. Gas phase phosphoric acid could thereby potentially be an elusive compound, which is not detected due to either low concentrations, and/or alternatively due to a swift partitioning into the particle phase. To elucidate the effect of phosphoric acid in atmospheric cluster formation, we herein investigate the molecular interaction between $\mathrm{H}_{3} \mathrm{PO}_{4}$ and common atmospheric aerosol precursors $\left(\mathrm{H}_{2} \mathrm{O}, \mathrm{NH}_{3}\right.$ and $\left.\mathrm{H}_{2} \mathrm{SO}_{4}\right)$. The following four cluster formation reactions involving $\mathrm{H}_{3} \mathrm{PO}_{4}$ are investigated:

$$
\begin{aligned}
& \mathrm{H}_{3} \mathrm{PO}_{4}+\mathrm{H}_{2} \mathrm{O} \leftrightharpoons\left(\mathrm{H}_{3} \mathrm{PO}_{4}\right)\left(\mathrm{H}_{2} \mathrm{O}\right) \\
& \mathrm{H}_{3} \mathrm{PO}_{4}+\mathrm{NH}_{3} \leftrightharpoons\left(\mathrm{H}_{3} \mathrm{PO}_{4}\right)\left(\mathrm{NH}_{3}\right) \\
& \mathrm{H}_{3} \mathrm{PO}_{4}+\mathrm{H}_{3} \mathrm{PO}_{4} \leftrightharpoons\left(\mathrm{H}_{3} \mathrm{PO}_{4}\right)_{2} \\
& \mathrm{H}_{3} \mathrm{PO}_{4}+\mathrm{H}_{2} \mathrm{SO}_{4} \leftrightharpoons\left(\mathrm{H}_{3} \mathrm{PO}_{4}\right)\left(\mathrm{H}_{2} \mathrm{SO}_{4}\right)
\end{aligned}
$$

To compare with sulfuric acid, the formation reactions (R1)-(R4) are compared to the 
following sulfuric acid interactions:

$$
\begin{aligned}
\mathrm{H}_{2} \mathrm{SO}_{4}+\mathrm{H}_{2} \mathrm{O} & \leftrightharpoons\left(\mathrm{H}_{2} \mathrm{SO}_{4}\right)\left(\mathrm{H}_{2} \mathrm{O}\right) \\
\mathrm{H}_{2} \mathrm{SO}_{4}+\mathrm{NH}_{3} & \leftrightharpoons\left(\mathrm{H}_{2} \mathrm{SO}_{4}\right)\left(\mathrm{NH}_{3}\right) \\
\mathrm{H}_{2} \mathrm{SO}_{4}+\left(\mathrm{CH}_{3}\right)_{2} \mathrm{NH} & \leftrightharpoons\left(\mathrm{H}_{2} \mathrm{SO}_{4}\right)\left(\left(\mathrm{CH}_{3}\right)_{2} \mathrm{NH}\right) \\
\mathrm{H}_{2} \mathrm{SO}_{4}+\mathrm{H}_{2} \mathrm{SO}_{4} & \leftrightharpoons\left(\mathrm{H}_{2} \mathrm{SO}_{4}\right)_{2}
\end{aligned}
$$

These formation reactions represent some of the key interactions in atmospheric new particle formation such as the interaction between sulfuric acid and water (R5), the interaction with the most abundant atmospheric base ammonia (R6) and the dimer formation of sulfuric acid (R8). As amines are known to form strong clusters with sulfuric acid the interaction between sulfuric acid and dimethylamine (R7) is included as a comparison. From the cluster formation reactions (R1)-(R8) we explore whether phosphoric acid could potentially form clusters in the atmosphere.

\section{Computational Methodology}

All Density Functional Theory calculations have been performed in Gaussian 09, rev B [61]. Explicitly correlated coupled cluster calculations (CCSD(T)-F12a [62-64]) were run in MOLPRO 2012.1 [65]. Domain based local coupled cluster calculations (DLPNO-CCSD(T) [66, 67]) were performed in ORCA 3.0.3 [68]. Geometry optimization and frequency calculations were performed using the M06-2X, PW91 and $\omega \mathrm{B} 97 \mathrm{X}-\mathrm{D}$ functionals with the $6-31++\mathrm{G}(\mathrm{d}, \mathrm{p})$ and $6-311++\mathrm{G}(3 \mathrm{df}, 3 \mathrm{pd})$ basis sets. In several recent benchmarks these three functionals have proven to be among the most reliable density functionals with respect to calculating binding energies of molecular clusters relevant to the atmosphere [69-73]. Utalization of the smaller $6-31++\mathrm{G}(\mathrm{d}, \mathrm{p})$ basis set for optimizing the geometry and calculating the vibrational frequencies do not lead to large errors compared to the large $6-311++\mathrm{G}(3 \mathrm{df}, 3 \mathrm{pd})$ basis set for clusters involving sulfuric acid, ammonia, amines, organics and water [74]. This result is further tested in this study, to evaluate if it remains valid for phosphorus containing compounds.

The binding (free) energies of the studied clusters are calculated with respect to the monomers as follows:

$$
\begin{aligned}
& \Delta E_{\text {bind }}=E_{\text {cluster }}-\sum_{i} E_{\text {monomer }, i} \\
& \Delta G_{\text {bind }}=G_{\text {cluster }}-\sum_{i} G_{\text {monomer }, i}
\end{aligned}
$$

The binding free energy can be partitioned into a pure electronic contribution and a thermal contribution to the Gibbs free binding energy:

$$
\Delta G_{\text {bind }}=\Delta E_{\text {bind }}+\Delta G_{\text {thermal }}
$$

A pragmatic approach is to use DFT for obtaining the geometry and frequencies, hence the $\Delta G_{\text {thermal }}$ contribution, and then use a higher level of theory for obtaining the $\Delta E_{\text {bind }}$ value, calculated at the DFT geometry. This allows for the calculation of 
an approximate $\Delta G_{\mathrm{bind}}^{\mathrm{CCSD}(\mathrm{T})^{*}}$ value in the following manner:

$$
\Delta G_{\text {bind }}^{\mathrm{CCSD}(\mathrm{T})^{*}}=\Delta E_{\text {bind }}^{\mathrm{CCSD}(\mathrm{T})}+\Delta G_{\text {thermal }}^{\mathrm{DFT}}
$$

To thoroughly sample the configurational space we use a semi-empirically guided sampling technique which relies on numerous randomly generated conformations. Phosphoric acid exists in both a $\mathrm{C}_{1}$ and $\mathrm{C}_{3}$ conformation. At the $\operatorname{CCSD}(\mathrm{T}) /$ aug-cc-pV $(\mathrm{T}+\mathrm{d}) \mathrm{Z}$ level of theory [75] the $\mathrm{C}_{3}$ conformation has been identified to be $1.5 \mathrm{kcal} / \mathrm{mol}$ lower in energy than the $C_{1}$ conformation and we will only consider this conformer in the cluster sampling. The following sampling routine is applied:

- In each step 1000 randomly oriented molecules are randomly distributed around the target molecule/cluster.

- The 1000 structures are initially optimized using the semi-empirical PM6 method.

- For the converged structures a single-point M06-2X/6-31+G(d) energy is calculated.

- The structures are sorted, characterized by the total energy/dipole moment and different conformations are identified.

- Conformations within $15 \mathrm{kcal} / \mathrm{mol}$ of the lowest identified conformation are geometry optimized and frequencies are calculated at the M06-2X/6-31+G(d) level.

The identified different M06-2X/6-31+G(d) optimized conformations are subsequently refined using M06-2X with the $6-31++\mathrm{G}(\mathrm{d}, \mathrm{p})$ and $6-311++(3 \mathrm{df}, 3 \mathrm{pd})$ basis sets to yield the final structures. The lowest three conformations of these are further evaluated using the PW91 and $\omega$ B97X-D functionals with the 6-31++G(d,p) and 6-311++(3df,3pd) basis sets. As DFT can be prone to errors in the electronic binding energy, the single point energies of each conformation is evaluated at the CCSD(T)-F12a/VDZ-F12 level of theory. The final Gibbs free energy is presented as the average of all three values, for each basis set. To get an indication of the uncertainty in the molecular geometry using the different DFT functionals, the standard deviation $(\sigma)$ is calculated, and presented for each result.

\section{Results and Discussion}

\subsection{Assessment of Computational Methodology}

\subsubsection{Sensitivity of the Applied DFT Methods}

We have utilized the three functionals PW91, M06-2X and $\omega$ B97X-D in conjugation with both the $6-31++\mathrm{G}(\mathrm{d}, \mathrm{p})$ and $6-311++\mathrm{G}(3 \mathrm{df}, 3 \mathrm{pd})$ basis sets for optimizing the geometries and calculating the vibrational frequencies. To test the performance of the chosen functionals, the up to three lowest free energy conformations for each of the clusters formed in reaction (R1)-(R8) are analyzed. This yields a total of 15 formation free energies in the evaluation. The Gibbs free energy is partitioned into a pure electronic contribution $\Delta E$ and the thermal contribution to the Gibbs free energy $\Delta G_{\text {Thermal }}$, as shown in equation (3). Table 1 shows the mean absolute deviation in $\Delta G_{\text {Thermal }}$ between the $6-31++\mathrm{G}(\mathrm{d}, \mathrm{p})$ and $6-311++\mathrm{G}(3 \mathrm{df}, 3 \mathrm{pd})$ basis sets and the mean absolute deviation and maximum deviation between the DFT and $\operatorname{CCSD}(\mathrm{T})$ F12a/VDZ-F12 binding energies for the 15 tested clusters. 
Table 1.: Mean absolute deviation and maximum deviation (shown in parenthesis) in the thermal contribution to the free energy $\left(\Delta G_{\text {Thermal }}\right)$ and binding energy $(\Delta E)$ between DFT calculated with either the $6-31++\mathrm{G}(\mathrm{d}, \mathrm{p})$ or $6-311++\mathrm{G}(3 \mathrm{df}, 3 \mathrm{pd})$ basis sets and CCSD(T)-F12a/VDZ-F12 results. All values are shown in $\mathrm{kcal} / \mathrm{mol}$.

\begin{tabular}{lccc}
\hline \hline & $\Delta G_{\text {Thermal }}$ & $\Delta E_{6-31++\mathrm{G}(\mathrm{d}, \mathrm{p})}$ & $\Delta E_{6-311++\mathrm{G}(3 \mathrm{df}, 3 \mathrm{pd})}$ \\
\hline \hline M06-2X & $0.7(1.8)$ & $2.8(4.1)$ & $1.3(2.1)$ \\
PW91 & $0.2(0.5)$ & $1.9(4.1)$ & $1.0(1.8)$ \\
$\omega$ B97X-D & $0.2(0.8)$ & $1.4(2.6)$ & $0.3(0.6)$
\end{tabular}

The mean absolute deviations in $\Delta G_{\text {Thermal }}$ between the $6-31++\mathrm{G}(\mathrm{d}, \mathrm{p})$ and 6 $311++\mathrm{G}(3 \mathrm{df}, 3 \mathrm{pd})$ basis sets for the 15 clusters is found to be $0.7,0.2$ and $0.2 \mathrm{kcal} / \mathrm{mol}$ for M06-2X, PW91 and $\omega$ B97X-D, respectively. This implies that the molecular structures and frequencies can be obtained using the smaller $6-31++\mathrm{G}(\mathrm{d}, \mathrm{p})$ basis set without introducing severe errors. For all the functionals the binding energies agree better with the $\operatorname{CCSD}(\mathrm{T})-\mathrm{F} 12 \mathrm{a} / \mathrm{VDZ}-\mathrm{F} 12$ calculation when increasing the basis set from 6$31++\mathrm{G}(\mathrm{d}, \mathrm{p})$ to $6-311++\mathrm{G}(3 \mathrm{df}, 3 \mathrm{pd})$. The DFT binding energies are almost exclusively found to overbind compared to coupled cluster theory. This is most severely observed by the M06-2X functional in case of acid-acid interactions. Among the tested functionals it is seen that the $\omega$ B97X-D functional using the $6-311++\mathrm{G}(3 \mathrm{df}, 3 \mathrm{pd})$ basis set yield results in best agreement with the $\operatorname{CCSD}(\mathrm{T})-\mathrm{F} 12 \mathrm{a} / \mathrm{VDZ}-\mathrm{F} 12$ binding energy. These findings correlate well with our previous estimate for a test set of 107 atmospherically relevant molecular clusters [70]. This suggests that for the studied clusters containing phosphoric acid, it is sufficient to use a $6-31++\mathrm{G}(\mathrm{d}, \mathrm{p})$ basis set for obtaining the geometry and frequencies, and a correlated method such as CCSD(T)-F12a/VDZ-F12 is required to yield reliable single point energies.

\subsubsection{Application of the DLPNO Method}

Highly accurate CCSD(T)-F12a/VDZ-F12 calculations are not feasible on larger clusters than those calculated in reaction (R1)-(R8). To extend the current analysis to larger clusters we apply the DLPNO-CCSD(T) method. To assess the performance of the DLPNO method we compare it to the CCSD(T)-F12a/VDZ-F12 calculations for reaction (R1)-(R4) using different basis sets. The tight settings for DLPNO is also tested [76]. We use the geometries of all three functionals and both the $6-31++\mathrm{G}(\mathrm{d}, \mathrm{p})$ and $6-311++\mathrm{G}(3 \mathrm{df}, 3 \mathrm{pd})$ basis sets yielding a total of 24 values to be tested. Table 2 shows the mean absolute error (MAE), mean signed error (MSE), maximum error (MaxE) in the calculated binding energy of reaction (R1)-(R4). The presented standard deviation $(\sigma)$ is calculated based on the MAE. 
Table 2.: The mean, signed and maximum error in the DLPNO-CCSD $(\mathrm{T})$ binding energy using different basis sets compared to $\operatorname{CCSD}(\mathrm{T})-\mathrm{F} 12 \mathrm{a} / \mathrm{VDZ}-\mathrm{F} 12$ results. The standard deviation $\sigma$ is based on the MAE. All values are presented in $\mathrm{kcal} / \mathrm{mol}$.

\begin{tabular}{lcccc}
\hline \hline Method & MAE & MSE & MaxE & $\sigma$ \\
\hline \hline & & & & \\
cc-pvdz & 2.2 & -0.8 & 4.1 & 1.2 \\
cc-pvtz & 0.8 & 0.1 & 2.5 & 0.8 \\
cc-pvqz & 0.4 & 0.4 & 1.3 & 0.4 \\
cc-pvdz, tight PNO & 2.4 & -1.2 & 3.8 & 1.0 \\
cc-pvtz, tight PNO & 0.9 & -0.2 & 2.1 & 0.5 \\
& & & & \\
aug-cc-pvdz & 0.7 & 0.5 & 2.0 & 0.6 \\
aug-cc-pvtz & 0.1 & 0.0 & 0.4 & 0.1 \\
aug-cc-pvdz, tight PNO & 0.5 & 0.3 & 1.6 & 0.5 \\
aug-cc-pvtz, tight PNO & 0.3 & -0.3 & 0.7 & 0.3
\end{tabular}

For cc-pVxZ, with $\mathrm{x}=\mathrm{D}, \mathrm{T}$ and $\mathrm{Q}$ the mean absolute errors and maximum errors decrease with increasing basis set size. The standard deviation $(\sigma)$ based on the mean absolute error systematically decreases with increasing cardinal number. For cc-pVQZ the MAE is identical to the MSE, indicating a systematic underestimation of the binding energy. Including diffuse functions in the basis set greatly increase the basis set convergence and an aug-cc-pVTZ basis set is seen to yield low errors compared to the CCSD(T)-F12a/VDZ calculation. Including diffuse functions yield a result of at least one cardinal number higher than the cc-pVxZ basis sets. For cc-pVxZ, with $\mathrm{x}=$ $\mathrm{D}, \mathrm{T}$ using tight $\mathrm{PNO}$, gives higher mean errors, but slightly decrease the maximum error and the standard deviation. For aug-cc-pVDZ using tight PNO slightly improves the agreement with the CCSD(T)-F12a/VDZ-F12 binding energy, whereas the agreement is slightly worse for aug-cc-pVTZ. These findings indicate that using DLPNO$\operatorname{CCSD}(\mathrm{T})$ /aug-cc-pVTZ yield results in good agreement with CCSD(T)-F12a/VDZF12 at a significantly reduced cost and with applicability to larger clusters.

\subsubsection{Basis Set Superposition Errors}

A major concern when calculating binding energies with a finite basis set is the emergence of basis set superposition errors (BSSE). To estimate the BSSE of clusters consisting of phosphoric acid, the binding energies were evaluated using DLPNO$\operatorname{CCSD}(\mathrm{T})$ with aug-cc-pVxZ, with $\mathrm{x}=\mathrm{D}, \mathrm{T}, \mathrm{Q}$ and 5 both with and without using the counterpoise $(\mathrm{CP})$ correction scheme. Figure 1 shows the DLPNO-CCSD(T) binding energies as a function of cardinal number for the clusters formed in reaction (R1)-(R4) calculated on top of the M06-2X/6-311++G(3df,3pd) geometries. 


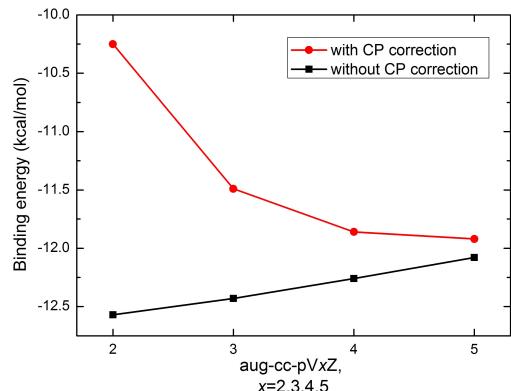

(a) $\left(\mathrm{H}_{3} \mathrm{PO}_{4}\right)\left(\mathrm{H}_{2} \mathrm{O}\right)$

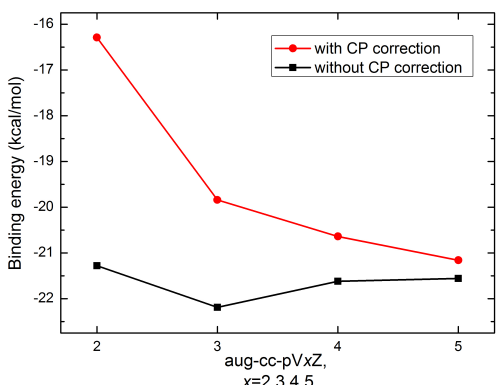

(c) $\left(\mathrm{H}_{3} \mathrm{PO}_{4}\right)\left(\mathrm{H}_{2} \mathrm{SO}_{4}\right)$

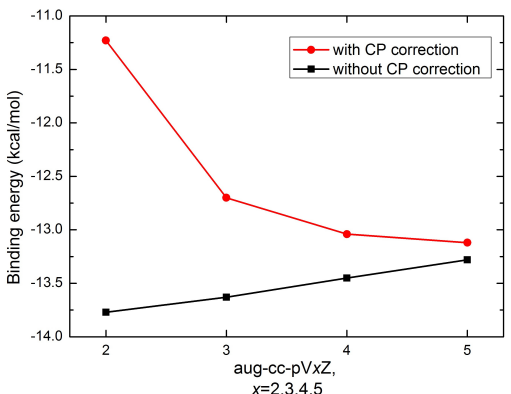

(b) $\left(\mathbf{H}_{3} \mathbf{P O}_{4}\right)\left(\mathbf{N H}_{3}\right)$

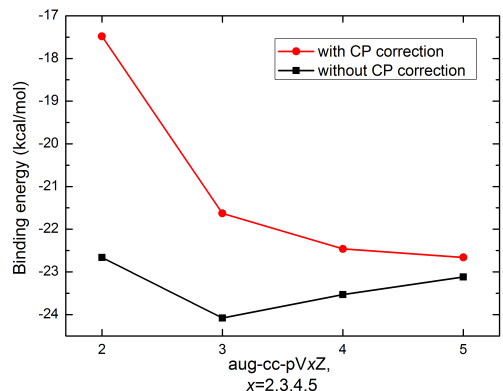

(d) $\left(\mathrm{H}_{3} \mathrm{PO}_{4}\right)_{2}$

Figure 1.: The DLPNO-CCSD $(\mathrm{T})$ binding energies with and without counterpoise correction (CP) as a function of cardinal number. The binding energies are presented in $\mathrm{kcal} / \mathrm{mol}$.

It is seen that the uncorrected (UC) and counterpoise (CP) corrected binding energies are approaching the same value, just from opposite sides, but even using aug-cc$\mathrm{pV} 5 \mathrm{Z}$ the values do not coincide. Using an aug-cc-pV5Z basis set the values between the UC and CP binding energies still differ by up to $0.6 \mathrm{kcal} / \mathrm{mol}$ for the $\left(\mathrm{H}_{3} \mathrm{PO}_{4}\right)_{2}$ dimer. Using the smaller aug-cc-pVDZ and aug-cc-pVTZ basis without CP is in better agreement with the basis set limit than with CP. Assuming the CP aug-cc-pV5Z value to be closes to the complete basis set limit we can compare this value to the UC value with smaller basis set to identify the potential error as shown in Table 3.

Table 3.: Calculated error in the uncorrected DLPNO binding energy relative to the counterpoise corrected aug-cc-pV5Z value. D and T refer to the aug-cc-pVDZ and aug-cc-pVTZ basis sets, respectively. Values are presented in $\mathrm{kcal} / \mathrm{mol}$.

\begin{tabular}{cccc}
\hline \hline Reaction & Cluster & $\mathrm{D}$ & $\mathrm{T}$ \\
\hline \hline R1 $)$ & $\left(\mathrm{H}_{3} \mathrm{PO}_{4}\right)\left(\mathrm{H}_{2} \mathrm{O}\right)$ & -0.7 & -0.5 \\
$(\mathrm{R} 2)$ & $\left(\mathrm{H}_{3} \mathrm{PO}_{4}\right)\left(\mathrm{NH}_{3}\right)$ & -0.7 & -0.5 \\
$(\mathrm{R} 3)$ & $\left(\mathrm{H}_{3} \mathrm{PO}_{4}\right)_{2}$ & -0.0 & -1.4 \\
$(\mathrm{R} 4)$ & $\left(\mathrm{H}_{3} \mathrm{PO}_{4}\right)\left(\mathrm{H}_{2} \mathrm{SO}_{4}\right)$ & -0.1 & -1.0
\end{tabular}


In all cases the UC value is seen to overbind compared to the CP DLPNO$\operatorname{CCSD}(\mathrm{T}) /$ aug-cc-pV5Z limit. The error does not necessarily go down when using the larger aug-cc-pVTZ basis set compared to aug-cc-pVDZ. For these systems this could indicate that if there is a large difference between the calculated binding energy using the aug-cc-pVDZ and aug-cc-pVTZ basis set one might suspect a large BSSE. As both the aug-cc-pVDZ and aug-cc-pVTZ basis sets were found to perform well compared to CCSD(T)-F12a/VDZ-F12 results as shown in previous section, we will use both when evaluating larger clusters in section 3.2.4.

\subsection{Molecular Interaction between $\mathrm{H}_{3} \mathrm{PO}_{4}$ and Nucleation Precursors}

\subsubsection{Molecular Structures}

From the systematic sampling technique, four different $\left(\mathrm{H}_{3} \mathrm{PO}_{4}\right)\left(\mathrm{H}_{2} \mathrm{O}\right)$ clusters were identified, while only two different $\left(\mathrm{H}_{3} \mathrm{PO}_{4}\right)\left(\mathrm{NH}_{3}\right)$ clusters were found. In Figure 2 the identified conformations with lowest free energy are depicted, calculated at the M06-2X/6-311++G(3df,3pd) level of theory.

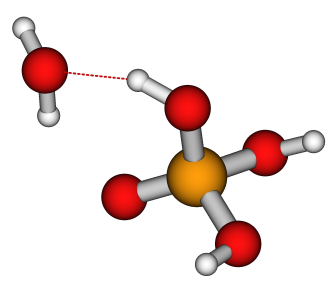

(a) $\left(\mathrm{H}_{3} \mathrm{PO}_{4}\right)\left(\mathrm{H}_{2} \mathrm{O}\right)(0.0)$

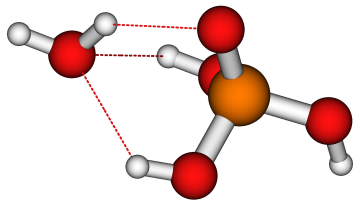

(d) $\left(\mathrm{H}_{3} \mathrm{PO}_{4}\right)\left(\mathrm{H}_{2} \mathrm{O}\right)(\mathbf{2 . 3})$

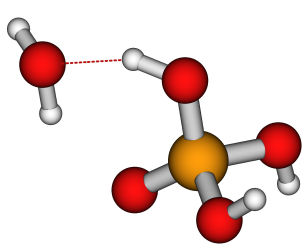

(b) $\left(\mathrm{H}_{3} \mathrm{PO}_{4}\right)\left(\mathrm{H}_{2} \mathrm{O}\right)(0.4)$

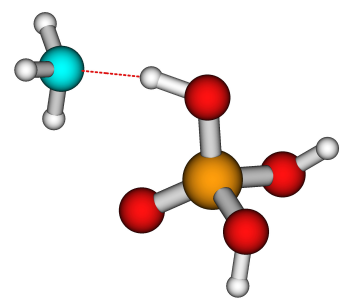

(e) $\left(\mathrm{H}_{3} \mathrm{PO}_{4}\right)\left(\mathrm{NH}_{3}\right)(\mathbf{0 . 0})$

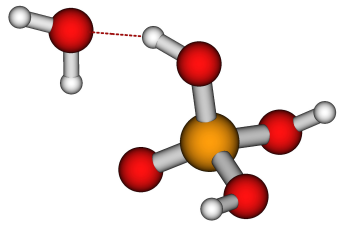

(c) $\left(\mathrm{H}_{3} \mathrm{PO}_{4}\right)\left(\mathrm{H}_{2} \mathrm{O}\right)(0.6)$

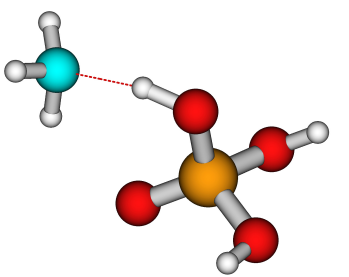

(f) $\left(\mathrm{H}_{3} \mathrm{PO}_{4}\right)\left(\mathrm{NH}_{3}\right)(\mathbf{0 . 3})$

Figure 2.: (a)-(d) The four identified conformations of the $\left(\mathrm{H}_{3} \mathrm{PO}_{4}\right)\left(\mathrm{H}_{2} \mathrm{O}\right)$ clusters and (e)-(f) the two identified conformations of the $\left(\mathrm{H}_{3} \mathrm{PO}_{4}\right)\left(\mathrm{NH}_{3}\right)$ clusters calculated at the M06-2X/6-311++G(3df,3pd) level of theory. The relative stability is given in the parenthesis in $\mathrm{kcal} / \mathrm{mol}$.

The different conformations of $\left(\mathrm{H}_{3} \mathrm{PO}_{4}\right)\left(\mathrm{H}_{2} \mathrm{O}\right)$ correspond to different rotations of the non-bonding $\mathrm{P}-\mathrm{OH}$ groups. There is only observed a slight elongation of the $\mathrm{OH}$ bond towards the water molecules with a length of $0.986 \AA$ compared to the length of $0.962 \AA$ of the two other $\mathrm{OH}$ groups which does not participate in hydrogen-bonding. For the formation of the $\left(\mathrm{H}_{3} \mathrm{PO}_{4}\right)\left(\mathrm{NH}_{3}\right)$ cluster the elongation of the $\mathrm{OH}$ bond is seen to be slightly higher with a value up to $1.020 \AA$. This indicates that the molecular interaction between phosphoric acid and ammonia is significantly stronger than the interaction with water.

A total of 45 different conformations of the $\left(\mathrm{H}_{3} \mathrm{PO}_{4}\right)\left(\mathrm{H}_{2} \mathrm{SO}_{4}\right)$ cluster was identified, with nine being within $3 \mathrm{kcal} / \mathrm{mol}$ of the lowest free energy minimum. In the case of 
the $\left(\mathrm{H}_{3} \mathrm{PO}_{4}\right)_{2}$ dimer 57 conformations were identified, with 17 being within $3 \mathrm{kcal} / \mathrm{mol}$ of the lowest free energy minimum. The potential energy surface for clusters involving $\mathrm{H}_{3} \mathrm{PO}_{4}$ is rather complex and involves numerous conformations. In Figure 3 the lowest identified three conformations of the $\left(\mathrm{H}_{3} \mathrm{PO}_{4}\right)\left(\mathrm{H}_{2} \mathrm{SO}_{4}\right)$ and the $\left(\mathrm{H}_{3} \mathrm{PO}_{4}\right)_{2}$ clusters are shown with their relative stabilities calculated at the M06-2X/6-311++G(3df,3pd) level of theory.

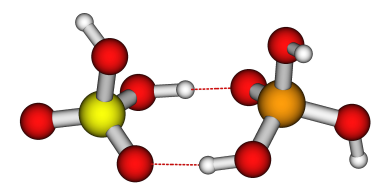

(a) $\left(\mathrm{H}_{3} \mathrm{PO}_{4}\right)\left(\mathrm{H}_{2} \mathrm{SO}_{4}\right)(0.0)$

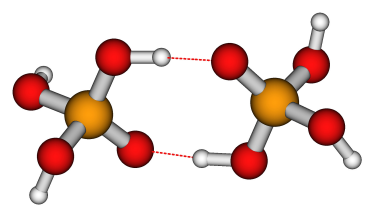

(d) $\left(\mathrm{H}_{3} \mathrm{PO}_{4}\right)_{2}(\mathbf{0 . 0})$

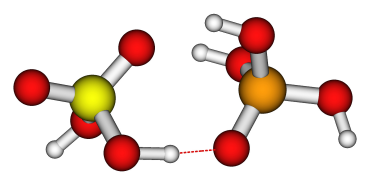

(b) $\left(\mathrm{H}_{3} \mathrm{PO}_{4}\right)\left(\mathrm{H}_{2} \mathrm{SO}_{4}\right)(0.6)$

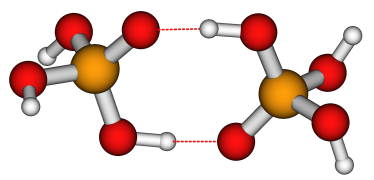

(e) $\left(\mathrm{H}_{3} \mathrm{PO}_{4}\right)_{2}(\mathbf{1 . 0})$

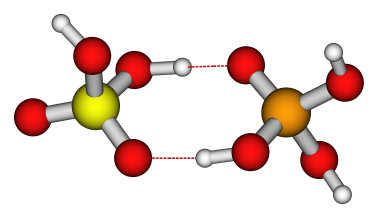

(c) $\left(\mathrm{H}_{3} \mathrm{PO}_{4}\right)\left(\mathrm{H}_{2} \mathrm{SO}_{4}\right)(0.7)$

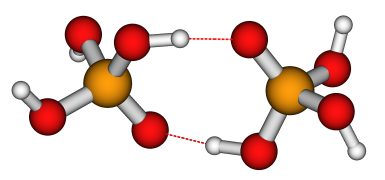

(f) $\left(\mathrm{H}_{3} \mathrm{PO}_{4}\right)_{2}(1.1)$

Figure 3.: The three lowest identified conformations of the $\left(\mathrm{H}_{3} \mathrm{PO}_{4}\right)\left(\mathrm{H}_{2} \mathrm{SO}_{4}\right)$ cluster (a)-(c) and the $\left(\mathrm{H}_{3} \mathrm{PO}_{4}\right)_{2}$ cluster (d)-(f) calculated at the M06-2X/6-311++G(3df,3pd) level of theory. The relative stability is given in the parenthesis in $\mathrm{kcal} / \mathrm{mol}$.

There is observed hydrogen bonded acid-acid interactions between $\mathrm{H}_{3} \mathrm{PO}_{4}$ and $\mathrm{H}_{2} \mathrm{SO}_{4}$. In the $\left(\mathrm{H}_{3} \mathrm{PO}_{4}\right)\left(\mathrm{H}_{2} \mathrm{SO}_{4}\right)$ cluster the sulfuric acid $\mathrm{S}-\mathrm{OH}$ bond is elongated up to $1.039 \AA$, whereas the phosphoric acid $\mathrm{OH}$ bond is only $0.991 \AA$. In case of the $\mathrm{H}_{3} \mathrm{PO}_{4}$ dimer there is seen an elongation of the $\mathrm{P}-\mathrm{OH}$ bond of up to $1.024 \AA$ in both $\mathrm{H}_{3} \mathrm{PO}_{4}$ molecules, which indicates strong hydrogen bonded interactions.

\subsubsection{Thermochemistry}

The Gibbs free energies of the clusters formed in reaction (R1)-(R8) are presented in Table 4. The molecular structures have been geometry optimized using DFT with either the $6-31++\mathrm{G}(\mathrm{d}, \mathrm{p})$ or $6-311++\mathrm{G}(3 \mathrm{df}, 3 \mathrm{pd})$ basis set and the single point energy has been calculated using CCSD(T)-F12a/VDZ-F12. The variation in the calculated single point energies thereby originate from the slightly different geometries of the clusters. The standard deviation $(\sigma)$ between the three calculated Gibbs free energies are presented in the parenthesis for both basis sets. 
Table 4.: Calculated average reaction free energies of formation for clusters involving $\mathrm{H}_{2} \mathrm{O}, \mathrm{NH}_{3},\left(\mathrm{CH}_{3}\right)_{2} \mathrm{NH}, \mathrm{H}_{2} \mathrm{SO}_{4}$ and $\mathrm{H}_{3} \mathrm{PO}_{4}$. The geometries and frequencies are calculated using DFT with either the $6-31++\mathrm{G}(\mathrm{d}, \mathrm{p})$ or $6-311++\mathrm{G}(3 \mathrm{df}, 3 \mathrm{pd})$ basis set. The single point energy is calculated using $\operatorname{CCSD}(\mathrm{T})-\mathrm{F} 12 \mathrm{a} / \mathrm{VDZ}-\mathrm{F} 12$. The standard deviation $\sigma$ is shown in the parenthesis. All values are shown in $\mathrm{kcal} / \mathrm{mol}$.

\begin{tabular}{cccc}
\hline \hline Reaction & Cluster & $\Delta G_{6-31++\mathrm{G}(\mathrm{d}, \mathrm{p})}$ & $\Delta G_{6-311++\mathrm{G}(3 \mathrm{df}, 3 \mathrm{pd})}$ \\
\hline \hline & & & \\
$(\mathrm{R} 1)$ & $\left(\mathrm{H}_{3} \mathrm{PO}_{4}\right)\left(\mathrm{H}_{2} \mathrm{O}\right)$ & $-0.7(0.2)$ & $-0.8(0.5)$ \\
$(\mathrm{R} 2)$ & $\left(\mathrm{H}_{3} \mathrm{PO}_{4}\right)\left(\mathrm{NH}_{3}\right)$ & $-2.2(0.3)$ & $-2.2(0.3)$ \\
$(\mathrm{R} 3)$ & $\left(\mathrm{H}_{3} \mathrm{PO}_{4}\right)_{2}$ & $-11.8(0.4)$ & $-12.1(0.2)$ \\
$(\mathrm{R} 4)$ & $\left(\mathrm{H}_{3} \mathrm{PO}_{4}\right)\left(\mathrm{H}_{2} \mathrm{SO}_{4}\right)$ & $-10.0(0.4)$ & $-10.6(0.8)$ \\
$(\mathrm{R} 5)$ & $\left(\mathrm{H}_{2} \mathrm{SO}_{4}\right)\left(\mathrm{H}_{2} \mathrm{O}\right)$ & $-1.6(0.1)$ & $-1.6(0.1)$ \\
$(\mathrm{R} 6)$ & $\left(\mathrm{H}_{2} \mathrm{SO}_{4}\right)\left(\mathrm{NH}_{3}\right)$ & $-5.2(0.1)$ & $-5.6(0.4)$ \\
$(\mathrm{R} 7)$ & $\left(\mathrm{H}_{2} \mathrm{SO}_{4}\right)\left(\left(\mathrm{CH}_{3}\right)_{2} \mathrm{NH}\right)$ & $-11.9(0.9)$ & $-11.9(0.2)$ \\
$(\mathrm{R} 8)$ & $\left(\mathrm{H}_{2} \mathrm{SO}_{4}\right)_{2}$ & $-5.9(0.3)$ & $-6.3(0.3)$
\end{tabular}

The reaction free energies are not very dependent on which basis set have been used for obtaining the geometries and vibrational frequencies, as also indicated in section 3.1.1. It is important to note that the sigma value does not necessarily go down when increasing the basis set size. In the following we will only comment on the free energies obtained using the structures optimized with the $6-31++\mathrm{G}(\mathrm{d}, \mathrm{p})$ basis set, as this level of theory will also be used to evaluate larger clusters in the following section.

The interaction between phosphoric acid and water (R1) is relatively weak, with a reaction free energy of $-0.7 \mathrm{kcal} / \mathrm{mol}$. Similarly, is seen for ammonia (R2), with a reaction free energy of $-2.2 \mathrm{kcal} / \mathrm{mol}$. These values are slightly less favourable than the corresponding values for the interaction between sulfuric acid and water (R5) and ammonia (R6), with reaction free energies of -1.6 and $-5.2 \mathrm{kcal} / \mathrm{mol}$, respectively. The weaker interaction can be rationalized from the fact that phosphoric acid is a slightly weaker acid than sulfuric acid. The interaction between phosphoric acid and sulfuric acid (R4) is strong, with a reaction free energy of $-10.0 \mathrm{kcal} / \mathrm{mol}$. The interaction between phosphoric acid and sulfuric acid is thereby close to the interaction between dimethylamine and sulfuric acid (R7) with a reaction free energy of $-11.9 \mathrm{kcal} / \mathrm{mol}$. The formation of the phosphoric acid dimer (R3) is twice as favourable as the sulfuric acid dimer (R8) with a reaction free energy of -11.8 $\mathrm{kcal} / \mathrm{mol}$ compared to $-5.9 \mathrm{kcal} / \mathrm{mol}$. Parts-per-trillion levels of dimethylamine has recently been shown to mimic ambient atmospheric new particle formation rates via an acid-base reaction stabilization mechanism. As phosphoric acid shows similar reaction free energies it could indicate that phosphoric acid could yield a similar stabilization as dimethylamine, although via an acid - acid stabilization mechanism. The phosphoric acid - sulfuric acid interaction is significantly more favourable than the corresponding sulfuric acid dimer formation. This further indicates that phosphoric acid could be a potential participant in atmospheric new particle formation.

It is curious that phosphoric acid interacts weakly with water and bases, yet have a strong interaction with sulfuric acid. To further look into this aspect, we evaluate the gas-phase proton affinities of the two acids. The proton affinities $(\Delta H)$ for each reaction have been calculated in a similar manner as the reaction free 
energies:

$$
\Delta H^{\mathrm{CCSD}(\mathrm{T})^{*}}=\Delta E^{\mathrm{CCSD}(\mathrm{T})}+\Delta H_{\mathrm{thermal}}^{\mathrm{DFT}}
$$

This is evaluated using all three functionals (M06-2X, PW91 and $\omega$ B97X-D) with the 6-31++G(d,p) basis set and CCSD(T)-F12a/VDZ-F12 single point energy corrections. The presented value is then the average of all three results. All three functionals predicted the same structures to be lowest in free energy. The lowest free energy structure of the $\mathrm{H}_{3} \mathrm{SO}_{4}{ }^{+}$molecule was found to have $\mathrm{C}_{3}$ symmetry, while the lowest free energy structure of the $\mathrm{H}_{4} \mathrm{PO}_{4}{ }^{+}$molecule has $\mathrm{S}_{4}$ symmetry, as shown in Figure 4.

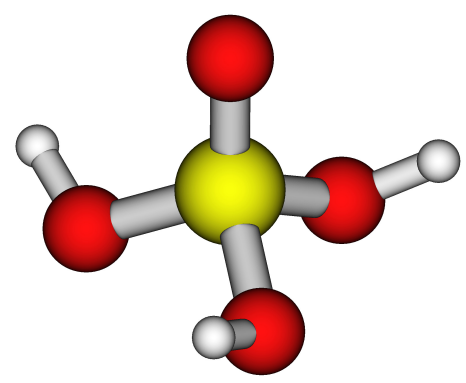

(a) $\mathrm{H}_{3} \mathrm{SO}_{4}^{+}$

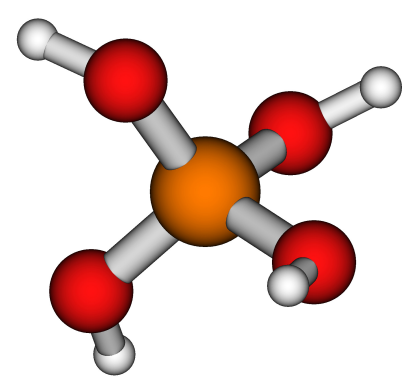

(b) $\mathrm{H}_{4} \mathrm{PO}_{4}^{+}$

Figure 4.: Molecular structures of (a) $\mathrm{H}_{3} \mathrm{SO}_{4}{ }^{+}\left(\mathrm{C}_{3}\right)$ and (b) $\mathrm{H}_{4} \mathrm{PO}_{4}{ }^{+}\left(\mathrm{S}_{4}\right)$ calculated at the M06-2X/6-31++G(d,p) level of theory.

For sulfuric acid and phosphoric acid we obtain the following proton affinities, with the standard deviation reported in the parenthesis:

$$
\begin{aligned}
\mathrm{H}_{2} \mathrm{SO}_{4} & \leftrightharpoons \mathrm{HSO}_{4}{ }^{-}+\mathrm{H}^{+} & & (\Delta H=+312.7(0.1) \mathrm{kcal} / \mathrm{mol}) \\
\mathrm{H}_{3} \mathrm{PO}_{4} & \leftrightharpoons \mathrm{H}_{2} \mathrm{PO}_{4}{ }^{-}+\mathrm{H}^{+} & & (\Delta H=+328.9(0.1) \mathrm{kcal} / \mathrm{mol}) \\
\mathrm{H}_{2} \mathrm{SO}_{4}+\mathrm{H}^{+} & \leftrightharpoons \mathrm{H}_{3} \mathrm{SO}_{4}{ }^{+} & & (\Delta H=-171.5(0.2) \mathrm{kcal} / \mathrm{mol}) \\
\mathrm{H}_{3} \mathrm{PO}_{4}+\mathrm{H}^{+} \leftrightharpoons & \leftrightharpoons \mathrm{H}_{4} \mathrm{PO}_{4}{ }^{+} & & (\Delta H=-199.8(0.2) \mathrm{kcal} / \mathrm{mol})
\end{aligned}
$$

The first two reactions represents the gas-phase acidity of sulfuric acid and phosphoric acid, while the remaining represents the gas phase basicity. The energy cost for removing a proton from sulfuric acid is lower than for phosphoric acid, with values of 312.7 $\mathrm{kcal} / \mathrm{mol}$ and $328.9 \mathrm{kcal} / \mathrm{mol}$, respectively. This suggests that sulfuric acid is a stronger acid in the gas-phase. Phosphoric acid has a higher gas-phase basicity than sulfuric acid with proton affinities of $-199.8 \mathrm{kcal} / \mathrm{mol}$ and $-171.5 \mathrm{kcal} / \mathrm{mol}$, respectively. This difference in acid/base strength explains why phosphoric acid has a weaker interaction than sulfuric acid with water and ammonia and also why the interaction between sulfuric acid and phosphoric acid is significantly stronger than the direct interaction between two sulfuric acid molecules. 


\subsubsection{Atmospheric Implications}

Currently, there is no available information about the atmospheric concentrations of phosphoric acid. To estimate the atmospheric impact of phosphoric acid, we compare reaction (R4) with reaction (R8).

$$
\begin{aligned}
& \mathrm{H}_{3} \mathrm{PO}_{4}+\mathrm{H}_{2} \mathrm{SO}_{4} \leftrightharpoons\left(\mathrm{H}_{3} \mathrm{PO}_{4}\right)\left(\mathrm{H}_{2} \mathrm{SO}_{4}\right) \\
& \mathrm{H}_{2} \mathrm{SO}_{4}+\mathrm{H}_{2} \mathrm{SO}_{4} \leftrightharpoons\left(\mathrm{H}_{2} \mathrm{SO}_{4}\right)_{2}
\end{aligned}
$$

Assuming mass-balance relations the following two equilibrium conditions are set up:

$$
\begin{aligned}
K_{1} & =\frac{\left[\left(\mathrm{H}_{2} \mathrm{SO}_{4}\right)_{2}\right]}{\left[\mathrm{H}_{2} \mathrm{SO}_{4}\right]^{2}} \\
K_{2} & =\frac{\left[\left(\mathrm{H}_{3} \mathrm{PO}_{4}\right)\left(\mathrm{H}_{2} \mathrm{SO}_{4}\right)\right]}{\left[\mathrm{H}_{3} \mathrm{PO}_{4}\right]\left[\mathrm{H}_{2} \mathrm{SO}_{4}\right]}
\end{aligned}
$$

To estimate at which point phosphoric acid becomes equally as important as sulfuric acid we set $\left[\left(\mathrm{H}_{2} \mathrm{SO}_{4}\right)_{2}\right]=\left[\left(\mathrm{H}_{3} \mathrm{PO}_{4}\right)\left(\mathrm{H}_{2} \mathrm{SO}_{4}\right)\right]$ and obtain:

$$
\begin{array}{r}
K_{1}\left[\mathrm{H}_{2} \mathrm{SO}_{4}\right]^{2}=K_{2}\left[\mathrm{H}_{3} \mathrm{PO}_{4}\right]\left[\mathrm{H}_{2} \mathrm{SO}_{4}\right] \\
\frac{K_{1}}{K_{2}}=\frac{\left[\mathrm{H}_{3} \mathrm{PO}_{4}\right]}{\left[\mathrm{H}_{2} \mathrm{SO}_{4}\right]} \exp \left(\frac{-\Delta \Delta G}{R T}\right)
\end{array}
$$

Here $\Delta \Delta G$ refer to the difference in reaction free energy between the formation of $\left(\mathrm{H}_{2} \mathrm{SO}_{4}\right)_{2}$ and $\left(\mathrm{H}_{3} \mathrm{PO}_{4}\right)\left(\mathrm{H}_{2} \mathrm{SO}_{4}\right)$. From Table 4 this corresponds to a $\Delta \Delta G$-value of $4.1 \mathrm{kcal} / \mathrm{mol}$. Atmospheric concentrations of sulfuric acid is typically found in the range $10^{5}-10^{7}$ molecules $/ \mathrm{cm}^{3}$. This implies that concentrations of $\mathrm{H}_{3} \mathrm{PO}_{4}$ approximately $10^{3}$ lower than sulfuric acid (i.e as low as $10^{2}-10^{4}$ molecules $/ \mathrm{cm}^{3}$ ) will yield the same stability for forming the dimer cluster. The formation of new particles have previously been shown to be very dependent on the formation of sulfuric acid dimers as a starting point for further growth [77]. These findings indicate that very low concentrations of phosphoric acid can potentially stabilize sulfuric acid clusters. It should, however, be noted that despite the high thermodynamic cluster stabilities, also kinetic limitations will inevitably restrict the atmospheric role of $\mathrm{H}_{3} \mathrm{PO}_{4}$ if its concentration is much lower than that of $\mathrm{H}_{2} \mathrm{SO}_{4}$. Since the stabilization between dimethylamine and sulfuric acid involves a proton transfer it implies that the acid to base ratio is required to be around 1. In case of the interaction between phosphoric acid and sulfuric acid there are still two P-OH groups available for further hydrogen bonding. In the following section we will investigate larger clusters involving phosphoric acid and sulfuric acid. This will allow the identification of whether a single phosphoric acid is able to stabilize several sulfuric acid molecules in larger clusters. 


\subsubsection{Larger Clusters}

To explore the potential to form larger clusters we have calculated the reaction free energy for forming the $\left(\mathrm{H}_{3} \mathrm{PO}_{4}\right)\left(\mathrm{H}_{2} \mathrm{SO}_{4}\right)_{2}$ cluster (R10):

$$
\begin{aligned}
\mathrm{H}_{2} \mathrm{SO}_{4}+\mathrm{H}_{2} \mathrm{SO}_{4} & \leftrightharpoons\left(\mathrm{H}_{2} \mathrm{SO}_{4}\right)_{2} \\
\left(\mathrm{H}_{2} \mathrm{SO}_{4}\right)_{2}+\mathrm{H}_{2} \mathrm{SO}_{4} & \leftrightharpoons\left(\mathrm{H}_{2} \mathrm{SO}_{4}\right)_{3} \\
\left(\mathrm{H}_{3} \mathrm{PO}_{4}\right)\left(\mathrm{H}_{2} \mathrm{SO}_{4}\right)+\mathrm{H}_{2} \mathrm{SO}_{4} & \leftrightharpoons\left(\mathrm{H}_{3} \mathrm{PO}_{4}\right)\left(\mathrm{H}_{2} \mathrm{SO}_{4}\right)_{2}
\end{aligned}
$$

The formation of the sulfuric acid dimer (R8) and trimer (R9) is included for comparison. The geometry and vibrational frequencies were calculated using M06-2X, PW91 and $\omega \mathrm{B} 97 \mathrm{X}-\mathrm{D}$ using the $6-31++\mathrm{G}(\mathrm{d}, \mathrm{p})$ basis set. The molecular structure of the $\left(\mathrm{H}_{3} \mathrm{PO}_{4}\right)\left(\mathrm{H}_{2} \mathrm{SO}_{4}\right)_{2}$ cluster was obtained in a similar fashion as outlined in section 2 and the lowest free energy conformation is depicted in Figure 5, calculated at the M06-2X/6-31++G(d,p) level of theory.

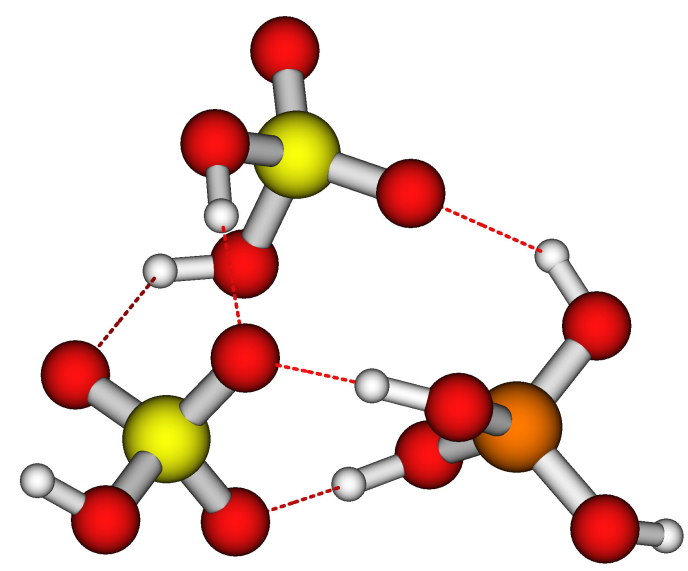

Figure 5.: Molecular structure of the $\left(\mathrm{H}_{3} \mathrm{PO}_{4}\right)\left(\mathrm{H}_{2} \mathrm{SO}_{4}\right)_{2}$ cluster, calculated at the M06$2 \mathrm{X} / 6-31++\mathrm{G}(\mathrm{d}, \mathrm{p})$ level of theory.

The molecular structure involves a proton transfer from a sulfuric acid molecule to phosphoric acid, effectively making phosphoric acid act as a base in the cluster. This formally leads to the formation of a charge separated $\left(\mathrm{HSO}_{4}^{-}\right)\left(\mathrm{H}_{2} \mathrm{SO}_{4}\right)\left(\mathrm{H}_{4} \mathrm{PO}_{4}{ }^{+}\right)$cluster. The reaction free energy for the formation of the clusters in (R8)-(R10) is shown in Table 5. The single point energy has been corrected using DLPNO-CCSD(T) with both the aug-cc-pVDZ and aug-cc-pVTZ basis sets, and the final free energy is calculated as an average of all three values. As usual the uncertainty is estimated as one standard deviation $(\sigma)$. 
Table 5.: Calculated average reaction free energies for clusters involving $\mathrm{H}_{2} \mathrm{SO}_{4}$ and $\mathrm{H}_{3} \mathrm{PO}_{4}$. The geometries and frequencies are calculated using DFT with the 6$31++\mathrm{G}(\mathrm{d}, \mathrm{p})$. The single point energy is calculated using DLPNO-CCSD $(\mathrm{T})$ with either the aug-cc-pvdz (D) or aug-cc-pvtz (T) basis set. The standard deviation $\sigma$ is shown in the parenthesis. All values are shown in $\mathrm{kcal} / \mathrm{mol}$.

\begin{tabular}{cccc}
\hline \hline Reaction & Cluster & $\mathrm{D}$ & $\mathrm{T}$ \\
\hline \hline (R8) & $\left(\mathrm{H}_{2} \mathrm{SO}_{4}\right)_{2}$ & $-4.8(1.2)$ & $-6.0(0.0)$ \\
$(\mathrm{R} 9)$ & $\left(\mathrm{H}_{2} \mathrm{SO}_{4}\right)_{3}$ & $-4.7(0.4)$ & $-5.1(0.3)$ \\
$(\mathrm{R} 10)$ & $\left(\mathrm{H}_{3} \mathrm{PO}_{4}\right)\left(\mathrm{H}_{2} \mathrm{SO}_{4}\right)_{2}$ & $-7.0(0.8)$ & $-7.1(1.6)$
\end{tabular}

For the formation of the $\left(\mathrm{H}_{3} \mathrm{PO}_{4}\right)\left(\mathrm{H}_{2} \mathrm{SO}_{4}\right)_{2}$ cluster in reaction (R10) there is seen little difference between the results obtained using aug-cc-pVDZ and aug-cc-pVTZ. The formation of the sulfuric acid dimer (R8) show larger deviations between the two basis sets, but the values are still within one standard deviation. In the formation of the sulfuric acid trimer (R9) the two calculated values correspond rather well. Based on the DLPNO/aug-cc-pVTZ results the calculated reaction free energy for forming the $\left(\mathrm{H}_{3} \mathrm{PO}_{4}\right)\left(\mathrm{H}_{2} \mathrm{SO}_{4}\right)_{2}$ cluster via reaction (R10) is found to be $-7.1 \mathrm{kcal} / \mathrm{mol}$ with a $\sigma$-value of $1.6 \mathrm{kcal} / \mathrm{mol}$. As a comparison the reaction free energy for forming the sulfuric acid dimer (R8) or trimer (R9) is found to be $-6.0 \mathrm{kcal} / \mathrm{mol}$ and -5.1 $\mathrm{kcal} / \mathrm{mol}$, respectively. This suggests that the incorporation of phosphoric acid in even the smallest clusters enhances the further uptake of sulfuric acid molecules significantly compared to pure sulfuric acid clusters. This shows that phosphoric acid might act as an elusive participant in atmospheric new particle formation most likely going undetected due to minuscule concentrations. Field studies with focus on measuring phosphoric acid concentrations might thereby be valuable in the future.

\section{Conclusions}

We have investigated the molecular interaction between phosphoric acid and common atmospheric precursors $\left(\mathrm{H}_{2} \mathrm{O}, \mathrm{NH}_{3}\right.$ and $\left.\mathrm{H}_{2} \mathrm{SO}_{4}\right)$ for new particle formation. The interaction between phosphoric acid and water/ammonia is found to be weaker than the corresponding interaction between sulfuric acid and water/ammonia. Phosphoric acid form strong hydrogen bonded clusters with sulfuric acid, with a stabilizing effect of similar magnitude as dimethylamine. The formation of the phosphoric acid dimer is found to be twice as favourable as the sulfuric acid dimer. The strong interaction between phosphoric acid and sulfuric acid indicates that concentrations as low as $10^{2}-10^{4}$ molecules $/ \mathrm{cm}^{3}$ ) will yield identical stability as the sulfuric acid dimer. This indicates that low concentrations of phosphoric acid could potentially be important in the initial steps in new particle formation, by stabilizing existing sulfuric acid clusters. Furthermore, we identify that even a single phosphoric acid molecule is able to further enhance the uptake of sulfuric acid molecules. 


\section{Acknowledgement(s)}

Jonas Elm thanks the Carlsberg foundation for financial support. We thank Academy of Finland, ERC project 257360-MOCAPAF and ERC project 692891-DAMOCLES for funding and the CSC-IT Center for Science in Espoo, Finland, for computational resources.

\section{References}

[1] J. Haywood and O. Boucher, Rev. Geophys. 38 (4), 513-543 (2000).

[2] M. Sipilä, T. Berndt, T. Petäjä, D. Brus, J. Vanhanen, F. Stratmann, J. Patokoski, R.L. Mauldin, A.P. Hyvrinen, H. Lihavainen and M. Kulmala, Science 327 (5970), 1243-1246 (2010).

[3] M. Kulmala, H. Vehkamki, T. Petäjä, M.D. Maso, A. Lauri, V.M. Kerminen, W. Birmili and P. McMurry, J. Aerosol Sci. 35 (2), 143 - 176 (2004).

[4] J. Kirkby, J. Curtius, J. Almeida, E. Dunne, J. Duplissy, S. Ehrhart, A. Franchin, S. Gagne, L. Ickes, A. Krten, A. Kupc, A. Metzger, F. Riccobono, L. Rondo, S. Schobesberger, G. Tsagkogeorgas, D. Wimmer, A. Amorim, F. Bianchi, M. Breitenlechner, A. David, J. Dommen, A. Downard, M. Ehn, R. Flagan, S. Haider, A. Hansel, D. Hauser, W. Jud, H. Junninen, F. Kreissl, A. Kvashin, A. Laaksonen, K. Lehtipalo, J. Lima, E. Lovejoy, V. Makhmutov, S. Mathot, J. Mikkil, P. Minginette, S. Mogo, T. Nieminen, A. Onnela, P. Pereira, T. Petäjä, R. Schnitzhofer, J. Seinfeld, M. Sipilä, Y. Stozhkov, F. Stratmann, A. Tom, J. Vanhanen, Y. Viisanen, A. Vrtala, P. Wagner, H. Walther, E. Weingartner, H. Wex, P. Winkler, K. Carslaw, D. Worsnop, U. Baltensperger and M. Kulmala, Nature 476, 429 - 433 (2011).

[5] T. Kurtén, M.R. Sundberg, H. Vehkamäki, M. Noppel, J. Blomqvist and M. Kulmala, J. Phys. Chem. A 110, 7178-7188 (2006).

[6] T. Kurtén, L. Torpo, M.R. Sundberg, V. Kerminen, H. Vehkamäki and M. Kulmala, Atmos. Chem. Phys. 7, 2765-2773 (2007).

[7] T. Kurtén, L. Torpo, C. Ding, H. Vehkamäki, M.R. Sundberg, K. Laasonen and M. Kulmala, J. Geophys. Res. 112, D04210 (2007).

[8] L. Torpo, T. Kurtén, H. Vehkamäki, K. Laasonen, M.R. Sundberg and M. Kulmala, J. Phys. Chem. A 111, 10671-10674 (2007).

[9] J. Herb, A.B. Nadykto and F. Yu, Chem. Phys. Lett. 518, 7-14 (2011).

[10] J.W. DePalma, B.R. Bzdek, D.J. Doren and M.V. Johnston, J. Phys. Chem. A 116, 1030-1040 (2012).

[11] J.W. DePalma, D.J. Doren and M.V. Johnston, J. Phys. Chem. A 118, 5464-5473 (2014).

[12] C.N. Jen, P.H. McMurry and D.R. Hanson, J Geophys. Res. Atmos. 119, 7502-7514 (2014).

[13] T. Kurtén, V. Loukonen, H. Vehkamäki and M. Kulmala, Atmos. Chem. Phys. 8, 40954103 (2008).

[14] T. Kurtén, I.K. Ortega and H. Vehkamäki, J. Mol. Struc-theochem 901, 169-173 (2009).

[15] V. Loukonen, T. Kurtén, I.K. Ortega, H. Vehkamäki, A.A.H. Pádua, K. Sellegri and M. Kulmala, Atmos. Chem. Phys. 10, 4961-4974 (2010).

[16] A.B. Nadykto, F. Yu, M.V. Jakovleva, J. Herb and Y. Xu, Entropy 13, 554-569 (2011).

[17] P. Paasonen, T. Olenius, O. Kupiainen, T. Kurtén, T. Petäjä, W. Birmili, A. Hamed, M. Hu, L.G. Huey, C. Plass-Duelmer and et al, Atmos. Chem. Phys. 12, 9113-9133 (2012).

[18] M.J. Ryding, K. Ruusuvuori, P.U. Andersson, A.S. Zatula, M.J. McGrath, T. Kurtén, I.K. Ortega, H. Vehkamäki and E. Uggerud, J. Phys. Chem. A 116, 4902-4908 (2012).

[19] O. Kupiainen, I.K. Ortega, T. Kurtén and H. Vehkamäki, Atmos. Chem. Phys. 12, 35913599 (2012).

[20] A.B. Nadykto, J. Herb, F. Yu and Y. Xu, Chem. Phys. Lett. 609, 42-49 (2014). 
[21] A.B. Nadykto, J. Herb, F. Yu, Y. Xu and E.S. Nazarenko, Entropy 17, 2764-2780 (2015).

[22] S. Lv, Y. Liu, T. Huang, Y. Feng, S. Jiang and W. Huang, J. Phys. Chem. A 119, 3770-3779 (2015).

[23] D.J. Bustos, B. Temelso and G.C. Shields, J. Phys. Chem. A 118 (35), 7430-7441 (2014).

[24] J. Almeida, S. Schobesberger, A. Kürten, I.K. Ortega, O. Kupiainen-Määttä, A.P. Praplan, A. Adamov, A. Amorim, F. Bianchi, M. Breitenlechner and et al., Nature 502, 359-363 (2013).

[25] C.N. Jen, R. Bachman, J. Zhao, P.H. McMurry and D.R. Hanson, Geophys. Res. Lett. 43, doi:10.1002/ 2015GL066958 (2016).

[26] J. Elm, C.N. Jen, T. Kurtén and H. Vehkamäki, J. Phys. Chem. A 120, 3693-3700 (2016).

[27] R. Zhang, I. Suh, J. Zhao, D. Zhang, E.C. Fortner, X. Tie, L.T. Molina and M.J. Molina, Science 304, 1487-1490 (2004).

[28] A.B. Nadykto and F. Yu, Chem. Phys. Lett. 435, 14-18 (2007).

[29] R. Zhang, I. Suh, J. Zhao, D. Zhang, E.C. Fortner, X. Tie, L.T. Molina and M.J. Molina, Science 304, 1487-1490 (2004).

[30] T. Christoffersen, J. Hjorth, O. Horie, N. Jensen, D. Kotzias, L.L. Molander, P. Neeb, L. Ruppert, R. Winterhalter, A. Virkkula and et al., Atmos. Environ. 32 (10), 1657 - 1661 (1998).

[31] Y. Xu, A.B. Nadykto, F. Yu, L. Jiang and W. Wang, J mol. Struc.-THEOCHEM 951, 28-33 (2010).

[32] W. Xu and R. Zhang, J. Phys. Chem. A 116, 4539-4550 (2012).

[33] Y. Xu, A.B. Nadykto, F. Yu, J. Herb and W. Wang, J. Phys. Chem. A 114, 387-396 (2010).

[34] R. Zhang, L. Wang, A.F. Khalizov, J. Zhao, J. Zheng, R.L. McGraw and L.T. Molina, Proc. Natl. Acad. Sci. U.S.A. 106, 17650-17654 (2009).

[35] J. Zhao, A. Khalizov, R. Zhang and R.L. McGraw, J. Phys. Chem. A 113, 680-689 (2009).

[36] K.H. Weber, F.J. Morales and F. Tao, J. Phys. Chem. A 116, 11601-11617 (2012).

[37] K.H. Weber, Q. Liu and F. Tao, J. Phys. Chem. A 118, 1451-1468 (2014).

[38] X. Peng, Y. Liu, T. Huang, S. Jiang and W. Huang, Phys. Chem. Chem. Phys. 17, 9552-9563 (2015).

[39] S. Miao, S. Jiang, J. Chen, Y. Ma, Y. Zhu, Y. Wen, M. Zhang and W. Huang, RSC Adv. 5, 48638-48646 (2015).

[40] J. Elm, T. Kurtén, M. Bilde and K.V. Mikkelsen, J. Phys. Chem. A 118, 7892-7900 (2014).

[41] I.K. Ortega, N.M.D. and T Kurtén, M. Kulmala, C. Focsa and H. Vehkamäki, J. Phys. Chem. A. 120 (9), 1452-1458 (2016).

[42] J.W. Depalma, J. Wang, A.S. Wexler and M.V. Johnston, J. Phys. Chem. A. 119, 1119111198 (2015).

[43] J.D. Crounse, L.B. Nielsen, S. Jørgensen, H.G. Kjaergaard and P.O. Wennberg, J. Phys. Chem. Lett. 4 (20), 3513-3520 (2013).

[44] T. Jokinen, M. Sipilä, S. Richters, V. Kerminen, P. Paasonen, F. Stratmann, D. Worsnop, M. Kulmala, M. Ehn, H. Herrmann and . Berndt, Angew. Chem. Int. Ed. 53, 14596-14600 (2014).

[45] T. Jokinen, T. Berndt, R. Makkonen, V.M. Kerminen, H. Junninen, P. Paasonen, F. Stratmann, H. Herrmann, A.B. Guenther, D.R. Worsnop, M. Kulmala, M. Ehn and M. Sipilä, Proc. Natl. Acad. Sci. U.S.A. 112 (23), 7123-7128 (2015).

[46] T. Berndt, S. Richters, R. Kaethner, J. Voigtlnder, F. Stratmann, M. Sipilä, M. Kulmala and H. Herrmann, J. Phys. Chem. A 119 (41), 10336-10348 (2015).

[47] M.P. Rissanen, T. Kurtén, M. Sipilä, J.A. Thornton, J. Kangasluoma, N. Sarnela, H. Junninen, S. Jørgensen, S. Schallhart, M.K. Kajos and et al., J. Am. Chem. Soc. 136, 15596-15606 (2014).

[48] M.P. Rissanen, T. Kurtén, M. Sipilä, J.A. Thornton, O. Kausiala, O. Garmash, H.G. Kjaergaard, T. Petäja, D.R. Worsnop, M. Ehn and M. Kulmala, J. Phys. Chem. A 119, 4633-4650 (2015). 
[49] T. Kurtén, M.P. Rissanen, K. Mackeprang, J.A. Thornton, N. Hyttinen, S. Jørgensen and H.G. Kjaergaard, J. Phys. Chem. A. 119, 11366-11375 (2015).

[50] F. Riccobono, S. Schobesberger, C.E. Scott, J. Dommen, I.K. Ortega, L. Rondo, J. Almeida, A. Amorim, F. Bianchi, M. Breitenlechner and et al., Science 344, 717-721 (2014).

[51] M. Ehn, J.A. Thornton, E. Kleist, M. Sipilä, H. Junninen, I. Pullinen, M. Springer, F. Rubach, R. Tillmann, B. Lee and et al., Nature 506, 476-479 (2014).

[52] S. Schobesberger, H. Junninen, F. Bianchi, G. Lönn, M. Ehn, K. Lehtipalo, J. Dommen, S. Ehrhart, I.K. Ortega, A. Franchin and et al., Proc. Natl. Acad. Sci. U.S.A. 110 (43), 17223-17228 (2013).

[53] J. Elm, N. Myllys, N. Hyttinen and T. Kurtén, J. Phys. Chem. A 119, 8414-8421 (2015).

[54] J. Elm, N. Myllys, J. Luy, T. Kurtén and H. Vehkamäki, J. Phys. Chem. A p. DOI: 10.1021/acs.jpca.6b00677 (2016).

[55] D. Glindemann, M. Edwards and P. Kuschk, Atmos. Environ. 37, 2429-2433 (2003).

[56] D. Glindemann, M. Edwards, J. Liu and P. Kuschk, Ecol. Eng. 24, 457-463 (2005).

[57] W.M. Lewis, M.C. Grant and S.K. Hamilton, OIKOS 45 (3) (1985).

[58] S.C. Morton and M. Edwards, Crit. Rev. Env. Sci. Tec. 35, 333-364 (2005).

[59] A.S. Hansen, L. Du and H.G. Kjaergaard, J. Phys. Chem. Lett. 5, 4225-4231 (2014).

[60] K.H. Møller, A.S. Hansen and H.G. Kjaergaard, J. Phys. Chem. A 119, 10988-10998 (2015).

[61] Gaussian 09, Revision B.01, Gaussian 09, Revision B.01, M. J. Frisch, G. W. Trucks, H. B. Schlegel, G. E. Scuseria, M. A. Robb, J. R. Cheeseman, G. Scalmani, V. Barone, B. Mennucci, G. A. Petersson, H. Nakatsuji, M. Caricato, X. Li, H. P. Hratchian, A. F. Izmaylov, J. Bloino, G. Zheng, J. L. Sonnenberg, M. Hada, M. Ehara, K. Toyota, R. Fukuda, J. Hasegawa, M. Ishida, T. Nakajima, Y. Honda, O. Kitao, H. Nakai, T. Vreven, J. A. Montgomery, Jr., J. E. Peralta, F. Ogliaro, M. Bearpark, J. J. Heyd, E. Brothers, K. N. Kudin, V. N. Staroverov, T. Keith, R. Kobayashi, J. Normand, K. Raghavachari, A. Rendell, J. C. Burant, S. S. Iyengar, J. Tomasi, M. Cossi, N. Rega, J. M. Millam, M. Klene, J. E. Knox, J. B. Cross, V. Bakken, C. Adamo, J. Jaramillo, R. Gomperts, R. E. Stratmann, O. Yazyev, A. J. Austin, R. Cammi, C. Pomelli, J. W. Ochterski, R. L. Martin, K. Morokuma, V. G. Zakrzewski, G. A. Voth, P. Salvador, J. J. Dannenberg, S. Dapprich, A. D. Daniels, O. Farkas, J. B. Foresman, J. V. Ortiz, J. Cioslowski, and D. J. Fox, Gaussian, Inc., Wallingford CT, 2010 .

[62] H. Werner, T.B. Adler and F.R. Manby, J. Chem. Phys. 126, doi: 10.1063/1.2712434 (2007).

[63] T.B. Adler, G. Knizia and H. Werner, J. Chem. Phys. 127, doi: 10.1063/1.2817618 (2007).

[64] G. Knizia, T.B. Adler and H. Werner, J. Chem. Phys. 130, doi: 10.1063/1.3054300 (2009).

[65] MOLPRO, version 2012.1, a package of ab initio programs, H.-J. Werner, P. J. Knowles, G. Knizia, F. R. Manby, M. Schtz, P. Celani, T. Korona, R. Lindh, A. Mitrushenkov, G. Rauhut, K. R. Shamasundar, T. B. Adler, R. D. Amos, A. Bernhardsson, A. Berning, D. L. Cooper, M. J. O. Deegan, A. J. Dobbyn, F. Eckert, E. Goll, C. Hampel, A. Hesselmann, G. Hetzer, T. Hrenar, G. Jansen, C. Kppl, Y. Liu, A. W. Lloyd, R. A. Mata, A. J. May, S. J. McNicholas, W. Meyer, M. E. Mura, A. Nicklass, D. P. O'Neill, P. Palmieri, D. Peng, K. Pflger, R. Pitzer, M. Reiher, T. Shiozaki, H. Stoll, A. J. Stone, R. Tarroni, T. Thorsteinsson, and M. Wang, , see http://www.molpro.net.

[66] C. Riplinger and F. Neese, J. Chem. Phys. 138, doi: 10.1063/1.4773581 (2013).

[67] C. Riplinger and F. Neese, J. Chem. Phys. 139, doi: 10.1063/1.4821834 (2013).

[68] Neese F., WIREs Comput Mol Sci 2012, 2: 73-78 doi: 10.1002/wcms.81.

[69] J. Elm, M. Bilde and K.V. Mikkelsen, J. Chem. Theory Comput. 8, 2071-2077 (2012).

[70] J. Elm, M. Bilde and K.V. Mikkelsen, Phys. Chem. Chem. Phys. 15, 16442-16445 (2013).

[71] H.R. Leverentz, J.I. Siepmann, D.G. Truhlar, V. Loukonen and H. Vehkamäki, J. Phys. Chem. A 117, 3819-3825 (2013).

[72] N. Bork, L. Du and H.G. Kjaergaard, J. Phys. Chem. A 118, 1384-1389 (2014).

[73] N. Bork, L. Du, H. Reiman, T. Kurtén and H.G. Kjaergaard, J. Phys. Chem. A 118, 
$5316-5322(2014)$.

[74] J. Elm and K.V. Mikkelsen, Chem. Phys. Lett. 615, 26-29 (2014).

[75] M. Yekutiel, J.R. Lane, P. Gupta and H.G. Kjaergaard, J. Phys. Chem. A 114, 7544-7552 (2010).

[76] D.G.L. and M Sparta and M K Kesharwani and J M L Martin and F. Neese, J. Chem. Theory. Comput. 11, 1525-1539 (2015).

[77] T. Olenius, O. Kupiainen-Määttä, I.K. Ortega, T. Kurtén and H. Vehkamäki, J. Chem. Phys. 139, doi: 10.1063/1.4819024 (2013). 